International Journal of Management and Human Science

www.ijmhs.org

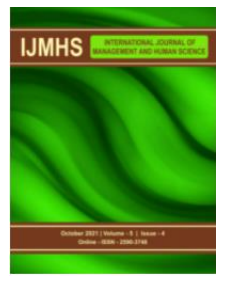

\title{
Effect of Forced Downsizing Strategies on Employees' Job Satisfaction
}

\author{
Mansour Alshrif Al-Hammali ${ }^{1}$, Nasser Habtoor ${ }^{2 *}$, Wee Huat Heng ${ }^{3}$ \\ ${ }^{1}$ Faculty of Leadership and Management, Universiti Sains Islam Malaysia, USIM, 71800, \\ Nilai, Malaysia \\ ${ }^{2}$ University of Jeddah \& University of Aden Jeddah, Saudi Arabia \\ ${ }^{3}$ Faculty of Business and Accountancy, Lincoln University College, 47301 Petaling Jaya, \\ Selangor D. E., Malaysia
}

*Corresponding Author's E-Mail: nhabtoor@uj.edu.sa

\begin{abstract}
Survivors from downsizing maybe they will lose their interest in jobs after undertaken the process of downsizing in which this can affect job satisfaction within organizations. Through the Libyan education sector, the current study investigates the impact of forced downsizing techniques on job satisfaction. The research sample was drawn from few divisions from the ministry of education located in different parts in Tripoli, Libya. A total of 258 completed surveys were gathered, producing a 73.7 percent response rate. The results show that downsizing has a detrimental impact on survivors' work satisfaction and morale. Based on the conclusion made, policymakers in Libyan education sector must support survivors more dynamically with respect to their upcoming prospects since downsizing was found to have an influence on their job satisfaction.
\end{abstract}

Keywords: Forced Downsizing Strategies; Employees’ Job Satisfaction

\section{Introduction}

Downsizing is a policy that has been utilised by many organisations in the last two decades to address the issues that have arisen as a result of the increased environmental competitiveness of business demands. In January 2007, Libyan authorities announced that more than a third of the country's civil officials would be laid off as part of the country's national budget preparations (Otman \& Karlberg, 2007). Consequently, the education sector, as a main sector in the country, presented by the Ministry of Higher Education has performed downsizing strategy to large number of employees working in the ministry (Al-Ali et al., 2019; 
Al-Awlaqi, Aamer, \& Habtoor, 2018; Al-Hammali, Habtoor \& Muthaliff, 2017; Etlesh, Habtoor \& Malik, 2017; Musbah \& Habtoor, 2015; Al-Shaibah \& Habtoor, 2015; Elmabruk, 2008). Official sources in the Ministry of Higher Education, however, were not aware of how the employer's drastic layoff will be carried out in practise, such as who will be asked to leave and under what conditions, or when they will be ordered out of office (Ismail et al., 2019; Saleh et al., 2018; Tabouli, Habtoor \& Nashief, 2016; Musbah, Habtoor \& Maram, 2016; Aldabbus, 2008). By large, the implemented downsizing strategy performed by the ministry had affected a large number of employees within this organization.

\subsection{Effect of Downsizing on Survivors' Job Satisfaction}

Organizational Transformation (Organizational change) Downsizing could result in increased workloads, work stress, and job uncertainty. It could cause family strife, which could lead to job unhappiness (Salama et al., 2020; Fathallah, Ameen \& Habtoor, 2020; Habtoor, 2018; Tabouli et al., 2016; Al-Shaibah, Habtoor \& Noor, 2017; Nadeem \& Abbas, 2009). In an effort to address this issue, the article titled "Downsizing and Restructuring: Lessons from the Firing Line for Revitalizing Organizations" survivor syndrome refers to the numerous types of behaviours and emotions displayed by employees in the aftermath of an organization's downsizing (Salama, Habtoor \& Isaac, 2019; Salah \& Habtoor, 2017; Ramadan, Habtoor \& Abdalla, 2015; Mohamed, Habtoor \& Mutalib, 2016; Al-Shaibah \& Habtoor, 2015; Burke \& Nelson, 2002).

Similarly, Burke \& Nelson (2002) state that survivors may lose interest in their work after going through a downsizing process, which can lead to high levels of job dissatisfaction inside businesses (Salama et al., 2020; Habtoor, 2020; Ismail et al., 2019; Chipunza \& Samuel, 2011). In a more recent study, nearly 700 UK managers were surveyed to determine the relationship between employee trust and productivity after a downsizing strategy was implemented. Finding revealed that, $60 \%$ felt employee loyalty had decreased due to redundancy, $76 \%$ felt morale had decreased and $59 \%$ perceived a decrease in motivation (Salama, Habtoor \& Isaac, 2019b; Habtoor, 2019; Worrall \& Cooper, 2012).

\subsection{Central Theme of the Paper}

Survivors are more loyal to the organisation if they believe the victims were adequately paid and treated decently (Habtoor et al., 2016; Habtoor, 2015; Gerber, 2010). In other words, when the organization could not manage the downsizing strategy accurately, as a result, survivors experience a wide variety of negative emotions and attitudinal responses such as exhaustion, depression. The goal of this article was to investigate the influence of forced downsizing tactics on employees' job satisfaction in the Libyan education sector, in order to overcome a lack of research in this field and fill this gap.

\section{Research Design and Methodology}

The impact of forced downsizing tactics on employee job satisfaction in the Libyan education sector was investigated using a quantitative methodology design, which appeared to be more appropriate. The drop-and-collect method was also implemented by picking numerous 
departments from the Libyan education ministry located in various districts of Tripoli. Respondents were selected using a stratified sampling method as recommended by Ibeh, Brock \& Zhou (2004). After all was said and done, 258 completed questionnaires were returned, producing a response percentage of $28 \%$. (73.7 percent).

\subsection{Reliability of the Questionnaire}

Within the scale, the Cronbach's Alpha was utilised to estimate the consistency of the individual respondent's response to items collected from the respondent's opinion of the influence of forced downsizing techniques on employees' job satisfaction in the Libyan education sector. Sekaran (2006) states that the closer the alpha value to 1 means the data is more reliable. Reliabilities less than 0.60 are deemed bad or non-acceptable, those between 0.60 and 0.70 are acceptable, and those over 0.80 are considered excellent (Nunnally, 1978). The general internal consistency of the items was first examined, and the results revealed a good Alpha value $(=0.79)$. As a result, it was determined that the goods were trustworthy and internally consistent.

\subsection{Statistical Analysis}

The study's demographic characteristics were analysed using descriptive statistics, such as frequencies, percentages, means, and standard deviations. In the Libyan education sector, the Pearson correlation coefficient was also used to assess the influence of forced reduction tactics on employee satisfaction.

\section{Results}

The following section described the characteristics of the respondents that participated in this survey based on their demographic profiles.

\subsection{Job Position}

Staffs were considered into categories such as program analyst, review officer, chief executive, officer, general manager, operational leader, senior manager, director and general manager as they have a practical experience in educational field. Their extensive experiences are a good starting point for determining the impact of downsizing tactics on job satisfaction in the Libyan education sector. They have worked in a variety of educational settings.

\section{Table 1}

\begin{tabular}{|c|c|c|c|}
\hline No. & Respondent's Job Title & Frequency & Percentage (\%) \\
\hline 1 & Senior Manager & 44 & $17.10 \%$ \\
\hline 2 & Program Analyst & 40 & $15.50 \%$ \\
\hline 3 & Director & 37 & $14.30 \%$ \\
\hline 4 & General Manager & 34 & $17.10 \%$ \\
\hline 5 & Operational Leader & 33 & $12.80 \%$ \\
\hline 6 & Chief Executive & 31 & $9.55 \%$ \\
\hline 8 & Officer & 15 & $4.35 \%$ \\
\hline
\end{tabular}




\begin{tabular}{|l|c|c|c|}
\hline $\mathbf{7}$ & Review Officer & 13 & $5 \%$ \\
\hline $\mathbf{9}$ & Educational Advisor & 11 & $4.30 \%$ \\
\hline \multicolumn{2}{|c|}{ Total No. of Respondents } & $\mathbf{2 5 8}$ & $\mathbf{1 0 0 \%}$ \\
\hline
\end{tabular}

\subsection{Age of the Respondents}

Respondents were given the option of selecting from a variety of options that included their current age. "21 to 24 " years old, " 25 to 34 " years old, "35 to 44" years old, and "45" years old were the categories available. However, the majority of respondents (202 in total) said they were between the ages of 35 and 44, accounting for 78 percent of the total. The second-largest group, 44, identified their age as being between 25 and 34 years old, with 17 percent of respondents falling into this category. The third group, which accounted for $10 \%$ of the total, stated that they were over 45 years old. Only two individuals (1\%) said they were between the ages of 21 and 24 .

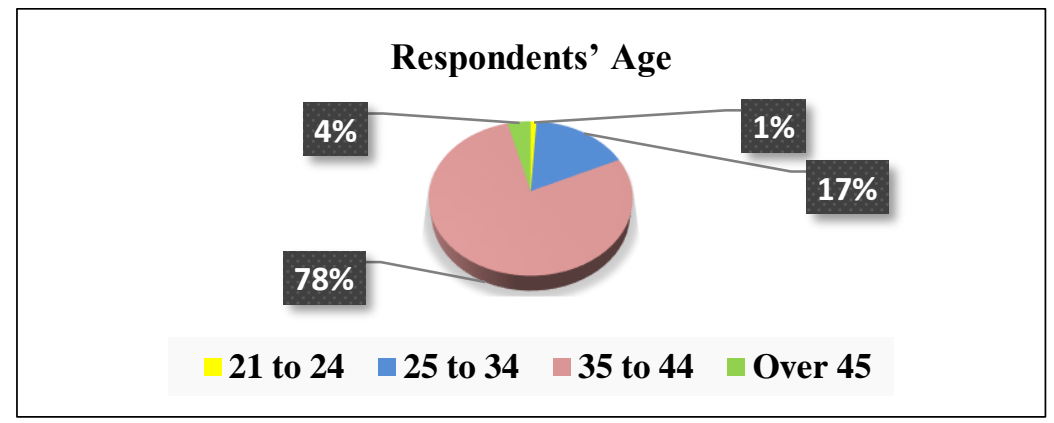

Figure 1

\subsection{Working Experience of the Respondents}

Many respondents' service lengths range from 10 to 15 years $(n=108,42 \%)$, as can be seen from the demographic data. Ninety-eight percent of the respondents $(n=98,38$ percent) had 5 to 10 years of job experience. Another group of respondents ( $n=35,13$ percent) stated that their employment experience was less than 5 years. In terms of working experience, the smallest group of respondents $(n=17.7 \%)$ had been in the workforce for more than 15 years.

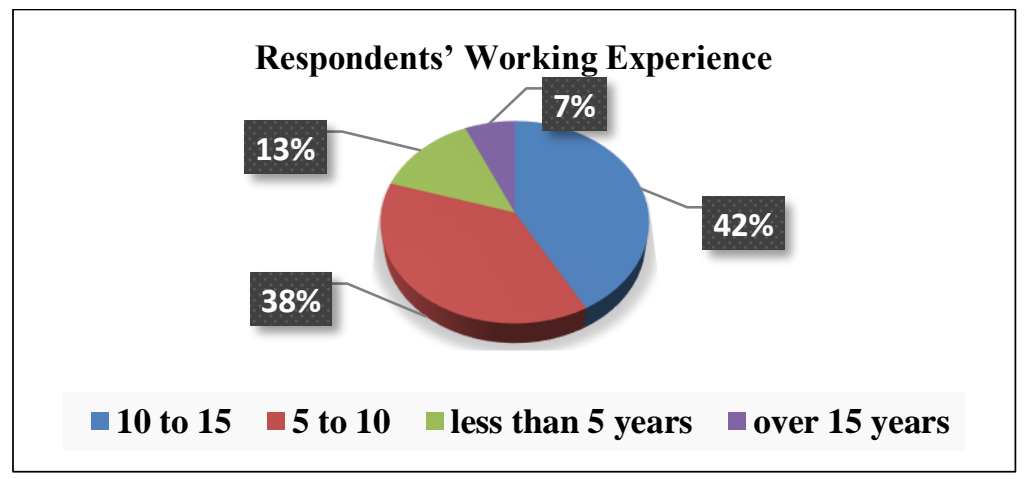

Figure 2

\subsection{Characteristics of the Respondents According to Their Gender}


From the Table 2 below, the total number of respondents is 258 consisting of male and female. The data suggest that males make up more than half of the responders, while females make up the rest. The results indicate that $67.05 \%$ of the male respondents provided answer to the questionnaire and the percentage of female who responded was below half (32.09\%). This indicates that the population of male was more than female. The next section illustrates the level of education of these respondents.

Table 2

\begin{tabular}{|c|c|c|c|c|c|}
\hline & Gender & Frequency & Percentage & $\begin{array}{c}\text { Valid } \\
\text { Percentage }\end{array}$ & $\begin{array}{c}\text { Cumulative } \\
\text { Percentage }\end{array}$ \\
\hline \multirow{2}{*}{ Valid } & Female & 85 & 32.09 & 32.09 & 32.09 \\
\cline { 2 - 6 } & Male & 173 & 67.05 & 67.05 & 67.05 \\
\hline & Total & 258 & 100.0 & 100.0 & \\
\hline
\end{tabular}

\subsection{Educational Qualification}

A cursory look at (Figure 3$)$ reveals that the largest group $(n=164,64 \%)$ reported holding a first degree. The second group $(n=63,24 \%)$ reported themself as master's degree holders. While the smallest group among respondents reported themself as Diploma holders (n $=31,12 \%$ ). The deduction from the above statistics is that most of the respondents have proper degrees; hence their involvement in decision is most likely.

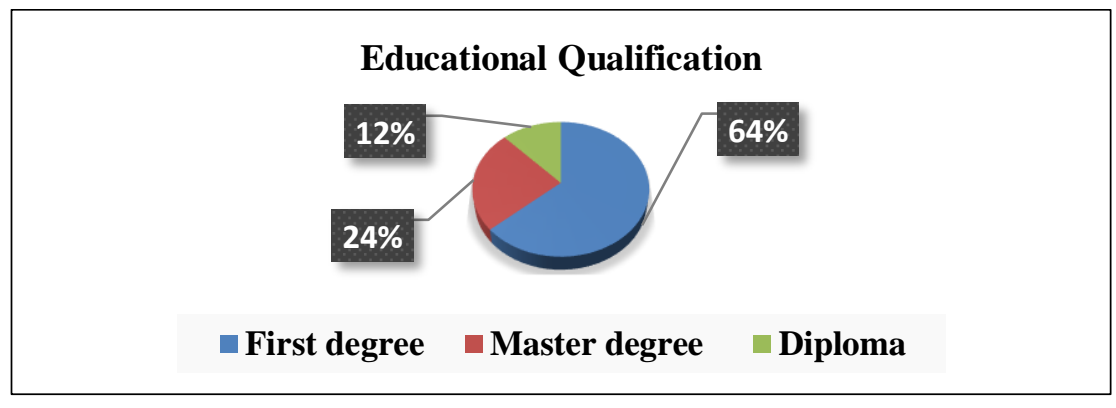

Figure 3

\subsection{Correlation Analysis}

Table 3 shows the relationships between work satisfaction indicators. Negatively connected with role stress ( $\mathrm{r}=-.496)$ and top management $(\mathrm{r}=-.218)$, and favourably correlated with Work Itself $(r=.42)$, Job Satisfaction with Immediate Supervision ( $r=.229)$ and Working Conditions ( $\mathrm{r}=.396)$.

Table 3: Correlations among Indicators for Job Satisfaction

\begin{tabular}{|c|c|c|c|c|c|c|c|}
\hline \multicolumn{2}{|c|}{$\begin{array}{c}\text { Indicators of Job } \\
\text { Satisfaction }\end{array}$} & SR & WI & IS & TM & WC & \\
\hline $\mathbf{1}$ & Stress Role & 1 & & & & & \\
\hline $\mathbf{2}$ & Work Itself & - & $\mathbf{1}$ & & & & \\
& & $.239^{* *}$ & & & & & \\
\hline
\end{tabular}


Int. J. Mgmt. Hum. Sci. 2021; 5(4): 1-10

\begin{tabular}{|c|c|c|c|c|c|c|c|}
\hline 3 & Immediate Supervision & $\begin{array}{c}- \\
.161^{* *} \\
\end{array}$ & $.113 * *$ & 1 & & & \\
\hline 4 & Top management & $.281 * *$ & $-.07 * *$ & $\begin{array}{c}- \\
.108 * *\end{array}$ & 1 & & \\
\hline 5 & Working Conditions & $\begin{array}{c}- \\
.236^{* *}\end{array}$ & $.411 * *$ & $.145^{* *}$ & $\begin{array}{c}- \\
.086^{* *}\end{array}$ & 1 & \\
\hline & Job Satisfaction & $\begin{array}{c}- \\
.496 * *\end{array}$ & $.42 * *$ & $.229 * *$ & $\begin{array}{c}- \\
.218^{* *}\end{array}$ & $.396 * *$ & $\mathbf{1}$ \\
\hline
\end{tabular}

Another correlation analysis was also undertaken to examine the obtained results from the rates of response of items extracted from job satisfaction parameters and response rate of downsizing parameters. The coefficient's value spans from negative $(-1)$ to positive $(+1)$, with a value of 0 indicating no association between the variables. According to Cohen et al. (2000), a correlation of 0.14 to 0.29 (+ or-) denotes a weak positive or negative link; 0.3 to 0.49 (+or) denotes a fair relationship; and 0.5 to 1.0 (+or-) denotes a significant positive or negative relationship.

Table 4: Correlation of Job Satisfaction Parameters and Response Rate of Downsizing Parameters

\begin{tabular}{|c|c|c|c|}
\hline \multicolumn{4}{|c|}{ Correlation } \\
\hline \multirow{7}{*}{$\begin{array}{c}\text { RATES OF RESPONSE OF } \\
\text { JOB SATISFACTION } \\
\text { PARAMETERS }\end{array}$} & \multicolumn{3}{|c|}{$\begin{array}{c}\text { LEVEL OF RESPONSE RATE OF } \\
\text { DOWNSIZING PARAMETERS }\end{array}$} \\
\hline & $\begin{array}{c}\text { Pearson } \\
\text { correlation }\end{array}$ & 1 & $\begin{array}{c}- \\
0.582^{* *}(\mathrm{~S})\end{array}$ \\
\hline & Sig. (2-tailed) & - & 0.000 \\
\hline & $\mathrm{N}$ & 258 & 258 \\
\hline & $\begin{array}{c}\text { Pearson } \\
\text { correlation }\end{array}$ & $-0.582 * *(\mathrm{~S})$ & 1 \\
\hline & Sig. (2-tailed) & 0.000 & - \\
\hline & $\mathrm{N}$ & 258 & 258 \\
\hline$S=$ Not Significant: $S=$ Sign & $n t / \alpha=0.05(L$ & f Significa & \\
\hline
\end{tabular}

Based on table 4, it was found that there was significant correlation among the rates of response of job satisfaction parameters and the level of response rate of downsizing parameters. Finding suggests that the employee's job satisfaction goes side by side with downsizing implementation in the Libyan situation. As a matter of fact, the correlation found here in this study is indicating that, authentic downsizing implementation is demonstrating high level of employee's job satisfaction. Such case should be recognized in the determination of successful downsizing implementation in Libyan education sector. 


\section{Discussion of Results in Relation to the Finding}

Very little effort has been done to discover the influence of downsizing strategy on job satisfaction of survivors' employees in in Libyan education sector. This study tried to dearth the earlier investigates gaps. In this study, it could thus be inferred from the findings that, there is a direct influence of downsizing on survivors' job satisfaction in Libyan education sector. Findings from the responses strongly show that top administration in Libyan education sector has not clarified staffs what is probable expected from them later after downsizing procedure and perhaps there were no open and truthful networks of communication and the facts that downsizing strategy is prearranged to employees only related to (Survivors). Therefore, this investigation make known that the implementation of downsizing strategy by Libyan education sector directly influences the job satisfaction and job security of survivors. Therefore, this research findings agreed with Kulkarni (2013) who in their work showed that before implementing downsizing organizations need conduct a firm analysis of condition and assess cost saving and be careful to approve such strategy that might influences negatively on staffs. Furthermore, job satisfaction in this study was defined as the factor that drives or boosts the action and behaviour of an individual towards effective accomplishment. Chipunza \& Samuel (2011) argue that job satisfaction must be the basis for concern with effective accomplishment, and that without job satisfaction, effective accomplishment has no purpose or meaning. This study put forward new contribution that is; the achievements of survivors in Libyan education sector and organizational goals in term of better educational program implementation in Libyan education sector are independent process linked by survivors' job satisfaction.

\section{Conclusions and Recommendations}

The aim of this paper was to determine the impact of forced downsizing strategies on employees' job satisfaction in Libyan education sector. In this study, it could thus be inferred from the findings that, there is a direct impact of downsizing on survivors' job satisfaction in Libyan education sector. Therefore, Policymakers in Libyan education sector must support survivors more dynamically with respect to their upcoming prospects since downsizing was found to have an influence on their job satisfaction. If Libyan organisations fail to provide survivors with new challenges or support them in pursuing new career options, their dissatisfaction with their jobs is likely to grow, and they may begin to question if staying was the correct decision. Given that a large percentage of participants expressed dissatisfaction with their work content, it is also proposed that managers give survivors with retraining so that they are better able to deal with their new tasks and sense joy rather than aggravation from completing them.

\section{Conflict of Interest}

The authors declared that they have no conflict of interest.

\section{Acknowledgement}


The authors are thankful to the institutional authority for completion of the work.

\section{References}

Al-Ali, A., Ameen, A., Issac, O., Habtoor, N., Nusari, M., Alrajawi, I. (2019). Investigate the Influence of Underlying Happiness Factors on the Job Performance on the Oil and Gas Industry in UAE. International Journal Of Management And Human Science, 2(4), 112.

Al-Awlaqi, M.A., Aamer, A.M., Habtoor, N. (2018). The effect of entrepreneurship training on entrepreneurial orientation: Evidence from a regression discontinuity design on micro-sized businesses. The International Journal of Management Education. researchgate.net/publication/332401820_The_effect_of_entrepreneurship_training_on _entrepreneurial

Al-Hammali, M.A., Habtoor, N., \& Muthaliff, M.M.A. (2017). Establishing Theoretical Perspectives: The Significant Influence of Downsizing as an Implemented Strategy on Survivors' Motivation. International Journal of Learning and Development, 7(1).

Al-Shaibah, M., Habtoor, N. (2015). Reward System and Job Satisfaction: A Conceptual Review. Global Advanced Research Journal of Management and Business Studies.

Al-Shaibah, M., Habtoor, N., \& Noor, K.B.M. (2017). Islamic Work Ethic and Employee' Performance with Mediation Effect of Job Satisfaction in Yemen. International Journal of Industrial Management.

Burke, R.J., \& Nelson, D.L. (2002). Downsizing and restructuring: lessons from the firing line for revitalizing organizations. Leadership \& Organization Development Journal, 18(7), 325-334.

Chipunza, C., \& Samuel, M.O. (2011). The Influence of Downsizing Organisational Strategies on Survivor Qualities in an Economically Volatile Environment. Journal of Social Science, 28(2), 87-98.

Etlesh, K.A.A., Habtoor, N., Malik, A.A. (2016). The Impact of Training on Crisis Management: Human Resource Development Mediation Variable Using (SEM). Asian Journal of Management Sciences \& Education, 5(3), 83-95.

Fathallah, A., Ameen, A., Habtoor, N. (2020). The Role of the Administrative Auditing in Improving Staff Performance: Theoretical Review. International Journal of Management and Human Science, 4(1), 11-22.

Gerber, N. (2010). Towards a social construction of retrenchment survivor experiences. South Africa: University of Pretoria. https://www.semanticscholar.org/paper/Towards-asocial-construction-of-retrenchment-

Gerber/48bd37d516aed6531ae860ae7ce5e9c48d62392d

Habtoor, N. (2015). The relationship between human factors and organizational performance. European Scientific Journal, 11(10), 17-29. 
Habtoor, N. (2016). Influence of human factors on organizational performance: quality improvement practices as a mediator variable. International Journal of Productivity and Performance Management, 65(4).

Habtoor, N. (2018). Factors Effecting Service Quality in the Malaysian Hospitality Sector, International Journal of Science and Research, 7(6).

Habtoor, N. (2019). Influence of management support on organizational commitment and service quality. Asian Journal of Management Sciences \& Education, 7(4), 47-51

Habtoor, N. (2020). Importance of Human Factors to Organizational Performance. International Journal of Management and Human Science, 4(1), 11-22

Habtoor, N. Zumrah, A.R.B., Disomimba, M.N, Samad, N.S.A. (2016). Effect of HRM Practices on Service Quality: Job Satisfaction as a Mediator Variable [Paper presentation]. In Proceedings of SOCIOINT 2016. 3rd International Conference on Education, Social Sciences and Humanities.

Ibeh, K., Brock, J.K.U., \& Zhou, Y. J. (2004). The drop and collect survey among industrial populations: theory and empirical evidence. Journal of Industrial Marketing Management, 33(2), 155-165.

Ismail, T.H.A., Ameen, A., Habtoor, N., \& Nusari, M. (2019). The Confirmatory Factor Analysis (CFA) of Motivation, Job Satisfaction, and Employee Performance. International Journal of Management and Human Science, 2(4), 73-83.

Kulkarni, P.P. (2013). A Literature Review on Training \& Development and Quality of Work Life. Journal of Researchers World, 4(2), 136.

Mohamed, M.M.K., Habtoor, N., Mutalib, M.B.A. (2016). Validity Selection for Building A Proposed Model for Human Resource Information System at the General Electricity Company of Libya Using Confirmatory Factor Analysis. Asian Journal of Management Sciences \& Education, 5(4), 77-87.

Musbah, A.R., \& Habtoor, N. (2015). Testing the validity of a Proposed model for Measuring Customer Satisfaction in Libyan Banks Using Confirmatory Factor Analysis. International Journal of Science and Research, 4(11).

Musbah, A.R., Habtoor, N., \& Abdalla, M.A.D. (2015). Sources of Administrative Leadership Strength and its Relationship with Training of Human Resources. Asian Journal of Management Sciences \& Education, 4(1).

Musbah, A.R., Habtoor, N., \& Maram, M. (2016). Testing the Model of Relationship and Impact of Administrative Leadership on Human Resource Training and Customer Satisfaction: Structural Equation Modeling (SEM). International Journal of Business and Management, 11(2).

Nunnally, J. C. (1978). Psychometric Theory (2 ${ }^{\text {nd }}$ ed.). McGraw-Hill.

Otman, W., \& Karlberg, E. (2007). The Libyan economy: economic diversification and international repositioning. Springer Science \& Business Media. 
Salah, H.M.R., Habtoor, N. (2017). Top Manager's Intention to Retain Older Employees in Libya Corporates Sector. International Journal Of Management And Human Science, $1(1), 1-12$

Salama, S., Habtoor, N., Isaac, O. (2019a). A Measurement Model for the Knowledge Management, Organizational Loyalty, and Staff Performance. International Journal of Management and Human Science, 3(3), 39-56.

Salama, S., Habtoor, N., Isaac, O. (2019b). The Proposed Theoretical Framework to Enhance the Impact of the A viability of the Infrastructure of Knowledge Management in Education Sector Staff Performance Efficiency. International Journal of Management and Human Science, 3(3), 39-56.

Salama, S., Habtoor, N., Isaac, O., \& Ameen, A. (2020). Impact of Availability of Knowledge Management Infrastructure on Improving the Performance of the Education Sector Staff in Libya: Organizational Loyalty as a Mediating Variable. International Journal of Management And Human Science, 4(1), 1-10.

Saleh, R.M.M., Nusari, M., Habtoor, N., \& Isaac, O. (2018). The effect of leadership style on organizational performance: Organizational commitment as a mediator variable in the manufacturing sector of Yemen. International Journal of Management and Human Science, 2(4), 13-24.

Sekaran, U. (2006). Research methods for business: A skill building approach. John Wiley \& Sons.

Tabouli, E.M., Habtoor, N., \& Nashief, M. (2016) The impact of human resources management on employee performance: organizational commitment mediator variable. Asian Social Science, 12(9). 